\title{
The Role and Importance of Financial Management in the Urban Development with the Light of the Impacts of Real Estate Market in Developing the Economic Growth in Egypt
}

\author{
Waleed Hussein Ali Hussein \\ Department of Architecture, Faculty of Engineering, Fayoum University, Fayoum, Egypt
}

Email address:

Dr_waleed@icloud.com

\section{To cite this article:}

Waleed Hussein Ali Hussein. The Role and Importance of Financial Management in the Urban Development with the Light of the Impacts of Real Estate Market in Developing the Economic Growth in Egypt. International Journal of Business and Economics Research.

Vol. 8, No. 6, 2019, pp. 347-357. doi: 10.11648/j.ijber.20190806.13

Received: August 22, 2019; Accepted: September 5, 2019; Published: September 25, 2019

\begin{abstract}
This paper adopts an inductive research approach and is divided into three sections. The first section is a theoretical inductive overview of Economics Market in Egypt and discusses the role of financial markets in resources mobilization and division of financial market in Egypt. Aiming to read the current situation of the Egyptian economic market. The second section describes the key players in the capital market by reviewing the role of financial markets economic growth. The third part introduces the reading in the real estate market in Egypt with Real Estate's Big Picture. The overall economic sector has a number of distinctive focal points, one of which is real estate, a primary sector of the economy. Between $30 \%$ and $50 \%$ of high and middle-income assets consist of real estate property and the percentage is even higher for lower-income Egyptian families. Moreover, the market capitalizations of land corporations publicly listed on the Egyptian Stock Market has been boosted by double-digit revenue growth, and the real estate sector has also been growing markedly at the macro level; with a growth rate exceeding $20 \%$, its overall contribution to GDP has surpassed $10 \%$. It is to be noted that the Egyptian real estate market is not one uniform sector; it is divided between principal residences located in Greater Cairo (mainly dominated by large and mid-scale developers), vacation homes on the coast (assorted real estate developers) and real estate in other areas across the country (generally developed by individual owners). Finally, with the results and recommendations, we will find that as a part of the whole urban development it is a very important part of the economic growth of Egypt.
\end{abstract}

Keywords: Real Estate, Financial Market, Money Market, Urban Growth, Economic Growth, Capital Market, Urban Development

\section{Introduction}

Financial markets play a vital role in the mobilization of monetary assets and economic resources for future investment through financial activity. Cash markets facilitate mercantilism in short-term debt instruments to satisfy the short-term needs of huge fund users, such as governments, banks and similar entities and establishments. Examples of such debt instruments include government treasury bills and similar securities as well as company business bills listed on the stock exchange. A wide variety of economic establishments, together with merchandiser banks, business banks, financial organizations and different dealers operate within the securities industry. Both public and non-public sector operators make use of various monetary instruments to boost and invest short-term funds that can be (and often are) swiftly liquidated to satisfy short-term needs when needed. Contrary to the financial market, the capital market directs long-term debt and equity finance to investments in longterm assets. Capital markets work in conjunction with the money market to facilitate the strengthening of company monetary structures and to improve the state of the national economy [1].

Capital market securities (risk capital or equity) and loan capital or debt) complement traditional lending institutions. By proposing the use of those instruments, the market is able to mobilize long-term savings and to supply investors with the needed capital to finance long-term investments, thus 
widening productive asset ownership. Financial dealers in the securities segment of the capital market act as intermediaries between the market and the public. They include banks, stockbrokers, investment and merchant bankers and venture capitalists. 2

Financial markets that function smoothly play a primary role in promoting global financial integration. A wellfunctioning domestic financial market can advance a nation's competitiveness in global capital markets.

When a country is able to access global capital markets through an efficient financial system, its dependence on foreign aid and other types of external borrowing diminishes. Financial analysts have indicated that financial globalization leads to the sharing of local security risks. In light of the benefits of efficient financial systems, several African countries have attempted to enact financial sector reforms. These have served as policy measures aimed at both promoting the development of domestic financial systems and removing obstacles to international capital flows. African money markets are increasingly being integrated with international capital markets and the active efforts to globalize capital flows have enhanced the relevance of emerging capital markets in Africa [2].

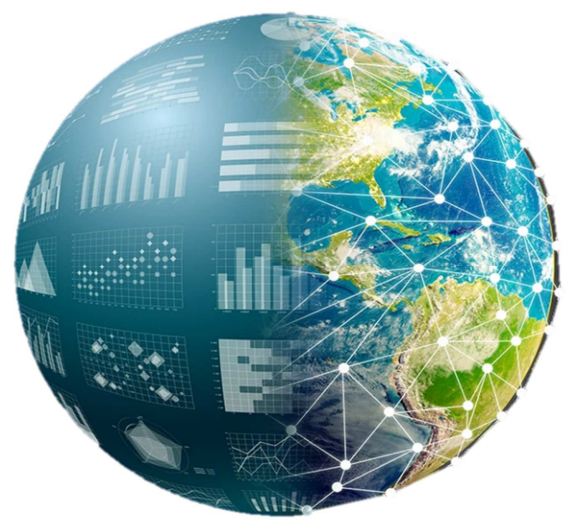

Figure 1. Capital Market regulatory 2019.

Source:

https://www.google.com/imgres?imgurl=https $\% 3 \mathrm{~A} \% 2 \mathrm{~F} \% 2 \mathrm{Fwww}$ 2.deloitte.c om $\% 2$ Fcontent $\% 2$ Fdam $\% 2$ FDeloitte $\% 2$ Fus\%2FImages $\% 2$ Fpromo_images

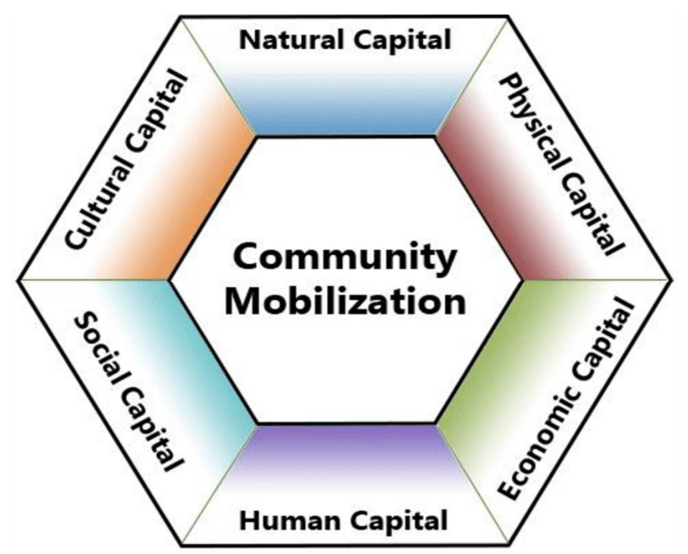

Source: https://www.google.com/search?newwindow

Figure 2. Community Mobilization.

\section{How Financial Markets Affect Resource Mobilization}

There are always individuals who prefer to keep the cash that they have and save it for future expenses or uses. These individuals are able to save because they have more money than they need to invest or spend at the time. There are also individuals who want to become involved monetary activities that they cannot afford. Either they don't have any financial resources or they don't have enough to cover the cost of the economic activity they want to undertake. For example, a person may not have the required cash to set up a small private business or to purchase houses or land. People such as these often need extra financial resources to cover the entire cost of their intended financial activity. The Legislature, for example, might want to build state-of-the-art emergency medical clinic or to construct a highway connecting the districts to neighborhoods. Nations such as Egypt might not have enough financial assets to realize such projects. In such cases, the government may need to rapidly acquire additional financing by borrowing money from the overall population. A second example would be that of a student who needs to borrow money because he doesn't have enough to pay his/her tuition fees. Or a company may be looking to build an additional manufacturing plant to expand its production in keeping with the increase in the demand for its products, but may not have the financial resources needed. That company's management may need to take out a loan. In every one of these cases, it is difficult to locate a person, or a group of persons, who can effectively provide the needed loans to the government, the student, the aspiring businessman / landowner and the company. Thus, most economies around the globe depend essentially on the market system to undertake the job of distributing hard to come by financial resources [4].

In economics, a market is a means (place or system) by which buyers and sellers can trade products and services. For the most part, goods and services are exchanged using accepted mediums (money is the most common example). The financial market is simply a market that deals with channeling financial assets from surplus units (savers) a to deficit units (such as governments, corporations or organizations that need additional financial resources to implement their activities). In any given economy, the money market is constituted of financial entities that borrow money from various types of savers (surplus units) through a process known as financial intermediation. A financial, or money, market is comprised of all the entities (known as financial intermediaries) that are involved in the financial intermediation process. Consequently, the financial market is a convenient means for the entrepreneur looking to finance his business, the government in need of additional funds to implement its projects, the student in search of a loan to pay tuition fees, and the firm in need of extra funds to construct a new plant [3].

Financial Market Structure

The financial market is comprised of two main components: the Money Market and the Capital Market. The Money Market, unlike the Capital Market, does not provide long-term 
capital; it encourages trade in short-lived debt instruments to fulfill the short-term requirements of large-scale fund users (governments, banks, and other large entities). These instruments include securities such as government treasury bills. However, since the industry bills of large firms are also unit samples listed on the market, many different monetary institutions trade in the monetary market, e.g. merchant, commercial and central banks. Additionally, individuals may establish financial instruments that enhance and invest in short-lived financial resources that can be immediately liquidated to fulfill short-term funding needs [5].

The Capital Market, on the other hand, is the component of the Financial Market that is used to activate the long-term financing of business enterprises and long-term government investments. The term Capital Market therefore refers to financial institutions that provide long-term (usually in excess of 12 months) loans to satisfy long-term capital needs. It is an efficient financial system that promotes the flow of financial assets from individuals who have surplus assets (savers) to individuals who need to use those assets (governments and private sector firms, for instance) to undertake long-term ventures. The Capital Market provides an opportunity for both individual investors / businessmen and governments to acquire large amounts of financial resources to fulfill their long-term credit needs through the purchase of financial securities [4].

The Capital Market has two components: the Primary Market and the Secondary Market. The Primary Market specializes in the trade of new securities. Companies that decide to sell (for example, in Initial Public Offerings) all or part of their stocks are listed on the Primary Market through the help of investment banks, brokerage companies and financiers (underwriter institutions). An IPO refers to the first time a company offers its securities to the public (lists its securities on a stock exchange). Money raised on the Primary Market is used to fund the issuing entity's operations. Purchasers of company shares (securities) can sell them on the Secondary Market to increase liquidity. The Secondary Market therefore provides a shopping platform for securities already held by the public (investors). The term 'investors' here refers to individuals or organizations that have purchased the securities (offers) issued by entities looking to realize financial returns. The Securities Market is therefore an organized financial market that trades in financial securities, on the Secondary Market; it provides a systematic, legitimate arrangement for trading in financial securities [11].

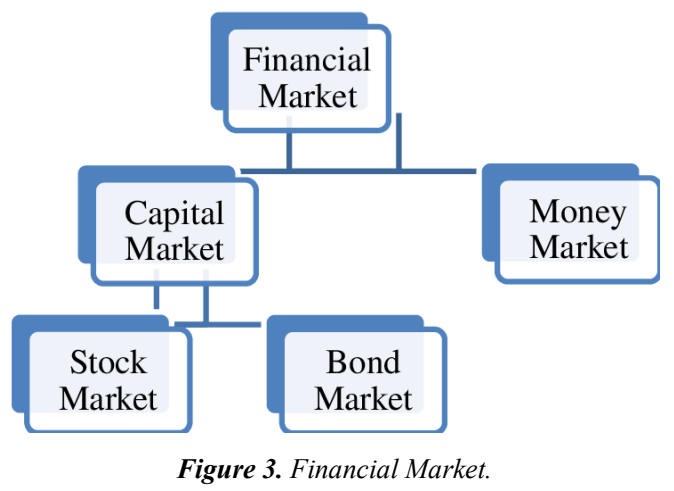

Source:

https://www.google.com/imgres?imgurl=http $\% 3 \mathrm{~A} \% 2 \mathrm{~F} \% 2 \mathrm{Fwww} \cdot$ binarytribu ne.com $\% 2$ Fwp-content $\% 2$ Fuploads $\% 2 F 2013 \% 2 F 12 \% 2 F 3$ 2_division-ofcaptial-

\section{Principal Actors in the Capital Market}

The principal actors in a well-organized stock exchange are the dealers / stockbrokerage firms, company registrars, issuing houses, mutual fund managers, investment banks, stock exchanges, the body in charge of regulating stock exchange activities (Security and Exchange Commission), the Central Security Clearing and Settlement (CSCS) system, public investors, accountants / auditors and lawyers [12].

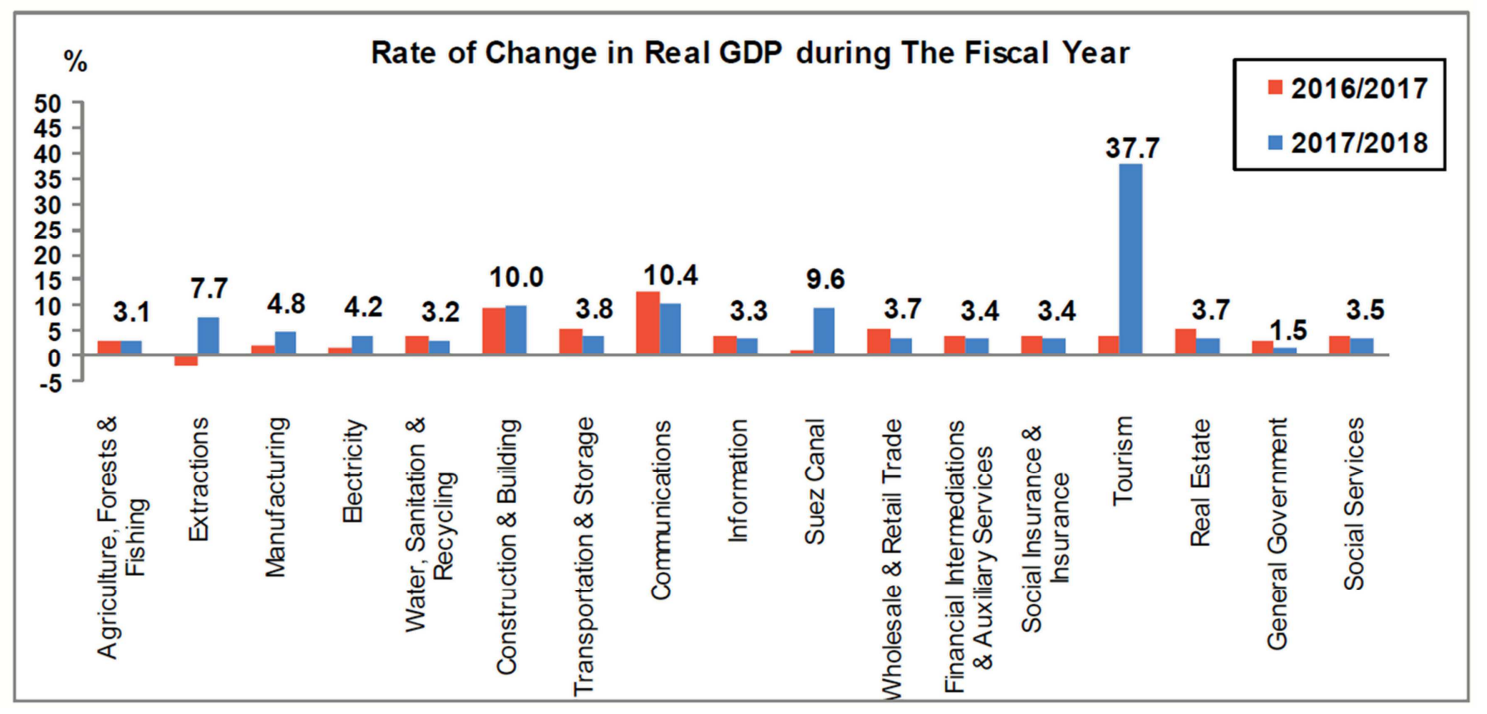

Source: Central Bank of Egypt

Figure 4. Real Estate and GDP Growth 


\author{
The Relationship between Financial Markets and \\ Economic Growth
}

Financial Markets are crucial to promoting economic process. An efficient, well-functioning financial sector boosts investment and encourages the formation of trade and business linkages, which helps to improve resource use and spread technological innovations. These markets galvanize investment in physical and human resources because they direct savings towards productive investment and promote capital inflows. Moreover, the financial sector collects and analyzes available information about investment opportunities, which serves to direct savings toward more productive uses. Some economists also maintain that the financial system can monitor management and apply corporate controls, thereby improving corporate efficiency [6].

Public and non-public sector operators use different financial instruments to enhance and invest short-term funds that they can quickly liquidate to fulfill short-term needs. For example, treasury notes or government bonds are financial instruments that governments use to finance long-term investment projects by borrowing money from the public. The money raised in this way may be spent on building public hospitals, roads, airports or dams or on enhancing public transport services and other social infrastructures - all of which creates national wealth that promotes economic growth [5].

The local government authorities in many countries resort to issuing municipal bonds to finance long-term projects (markets, recreational centers, roads, schools, hospitals, transport systems, and other services that generate regular sources of income). For instance, in Sierra Leone the Freetown City Council, as well the provincial councils, issue municipal bonds to develop social infrastructure [6].

Public firms may issue corporate bonds to raise money to spend on long-term development projects, such as new cities, new buildings, expanding standing factories or building new ones, introducing new technology, buying equipment and supplies, etc. Corporations can also raise needed financial resources for long-term investment by issuing equities (Common Stocks and Preferred Stocks) and using the proceeds to buy equipment, build manufacturing plants, expand corporation operations, etc. Through all of these activities, corporations are creating wealth using Financial Market instruments [12].

When investors shop for and trade in financial securities, they generate cash in the Capital Market. Investors who purchase debt instruments (government bonds, municipal bonds or corporate bonds) receive regular interest payments (the interest rate is specified in the loan contract) from the issuer of the debt security, as well as the principal amount at the end of the loan period. Of course, a higher interest rate on a debt security means interest payments will be higher. For example, an investor that purchases five-year government bonds worth LE 800,000 at an interest rate of $9 \%$ per annum will receive LE 1,230,899.16 at the end of the five-year period. The extra LE 430, 899.16 represents the interest payable to the investor for holding LE 800,000 worth of government bonds for a five-year period. If the interest were $12 \%$ per annum, the investor holding LE 800,000 worth of government bonds would receive LE 1, 409,873.35 at the end of the five-year period. In this case, the investor has generated LE 609,873.35 by holding LE 800, 000 in government bonds for five years. Thus, investors produce wealth within the capital market by using the financial instrument of debt securities [8].

An individual who invests in equities (Common and Preferred Shares or Stocks) becomes a shareholder or part owner of the firm issuing the equities. As such, the individual is entitled to a share of the firm's annual profits (a dividend). The amount of dividend investors are entitled to receive depends on the number of shares they hold and on the firm's dividend policy. A company may sometimes decide to issue additional shares to its shareholders rather than pay the dividend amounts in cash. Moreover, a shareholder could opt to sell his/her shares for financial gain. An investor who bought 2000 shares of a given company at LE 400.00 per share may later sell these shares at the price of LE 1000.00 per share, thereby realizing a capital gain of LE 1, 200,000.00. Dividends, bonus shares and capital gains resulting from the selling of shares all constitute wealth created by the investor [9].

\section{Real Estate's Big Picture}

\subsection{The Resilience of Real Estate}

Egypt's real estate sector has been resilient in the face of the economic and political upheavals that took place over the past decade, including the global recession of 2007-08 and two revolutions since 2011. And that has been a saving grace for the economy, as the sector employs about $5 \%$ of the country's labor force and feeds into more than 90 industries. Real estate has been growing tremendously since 2005 , often when the economy as a whole is sluggish, and since FY $2012 / 13$, the sector has consistently accounted for around $9 \%$ of total GDP. Despite slackened GDP growth following the 2011 Revolution, demand for properties has stayed strong, and a number of regional real estate developers have made themselves at home in the Egyptian market. To accommodate consumers during the economic and political uncertainty, real estate developers devised more flexible payment conditions and extended payment schemes, creating today's typical seven-to-10-year payment schedules for residential properties. While these initiatives contributed to the sector's growth and development, the many difficulties slowing down economic activity across the board in Egypt today are challenging the resilience of the real estate sector [10]. 


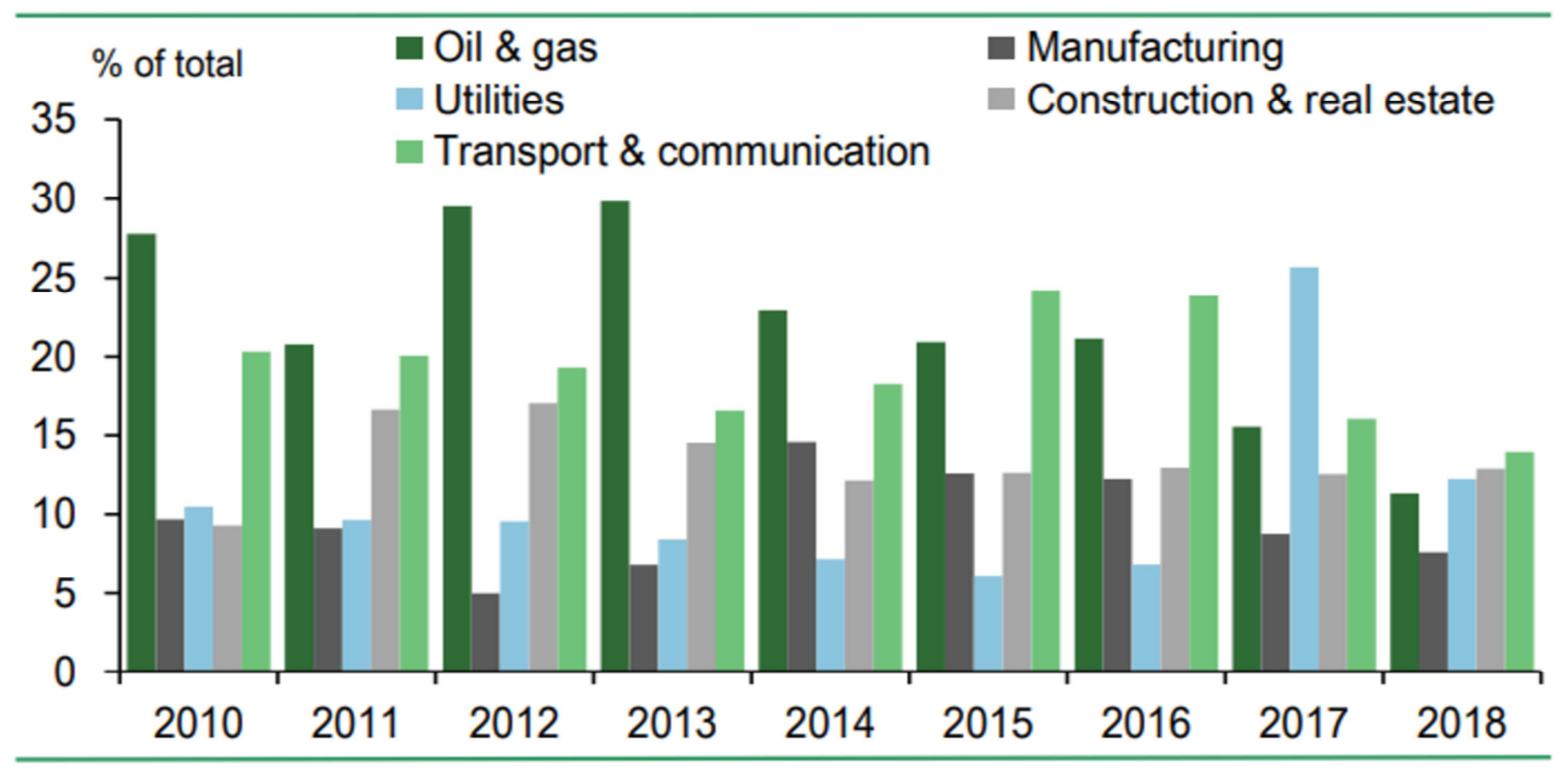

Source: Ministry of planning, Egypt

Figure 5. Real Estate Private Investment.

Total implemented real estate investments are generally dominated by the private sector, which has accounted for an average of $94 \%$ of total investments since 2005 . Investments by the private sector are primarily fixed on the high-end consumer market, representing no more than $15 \%$ of the population, due to its lucrative profit margins. Appealing to consumer aspirations for high-end living, real estate developers have invested heavily in building gated, selfsufficient, mixed-use communities located in Cairo's east and west suburbs. Since 2013, public investments have increased due to a portfolio of government-planned projects to shrink Egypt's housing deficit, which is estimated at 3.5 million units as of 2015. However, dwindling foreign currency reserves and a widening government deficit threaten to curb the level of public investment [7].

\subsection{Millennials Driving Demand}

Homeownership is an objective for most Egyptians, for both social and money related reasons. Development inland has in this way been firmly connected to the nation's socioeconomics. Egypt's populace is rising quickly when populace development is easing back in other worldwide locales, demonstrating an economical and stable stream of interest for lodging. In June 2016, the state measurements organization CAPMAS declared that the populace had arrived at 91 million, expanding by 1 million in just a half year. Somewhere in the range of 2005 and 2016, the populace demonstrated a CAGR of $2.4 \%$. The international real estate counseling firm Knight Straightforward predicts a $60 \%$ increase in Egypt's population by 2025. This dramatic increase is a godsend for the real estate sector because it ensures that individuals will be purchasing and selling homes for years to come [14].

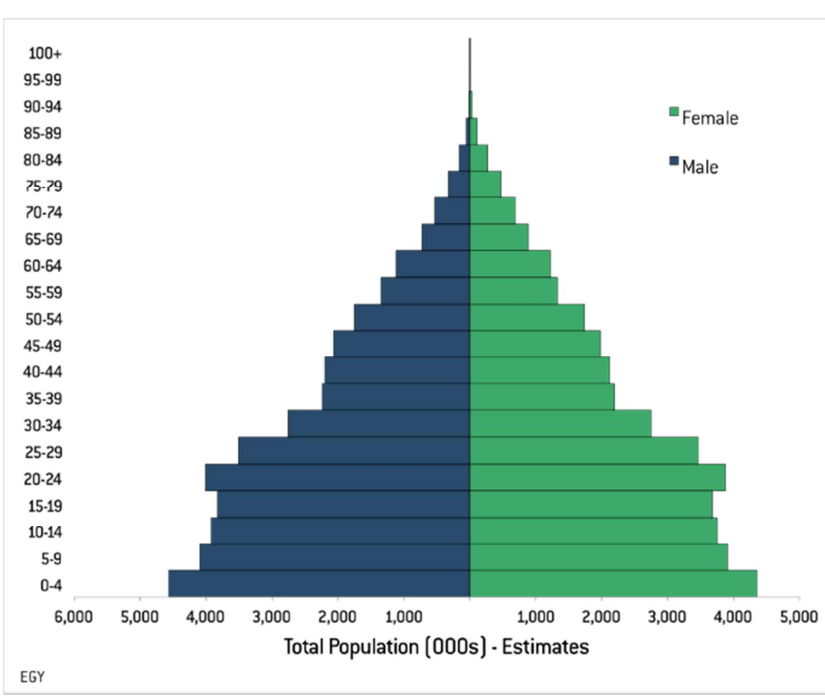

Figure 6. Egypt's Population by Age (2018)

Source:

https://www.google.com/search?newwindow=1\&tbm=isch\&sa=1\&ei=BVhe XduKFMSYaZ24o6AF\&q=Egypt $\%$ E2\%80\%99s + Population+by+Age $+\% 28$ $2016 \% 29 \&$ oq $=$ Egypt $\%$ E2\%80\%99s

However, it's Generation Y, called the Millennials, that are driving today's demand. Encompassing those born between 1980 and 2000, this generation accounts for nearly $40 \%$ of Egypt's population and over $90 \%$ of the country's workforce. Given their numbers, millennials constitute a primary engine of the economy that greatly affects consumption and spending. Moreover, the members of this generation who are between 25 and 35 years of age are in the heyday of their home-buying years [12].

According to CAPMAS, the typical age for a wedding in Egypt is between 25-27 years old; in 2015, there have been 
969,000 marriages registered, a $1.7 \%$ increase over the year before. As social norms have it, a few ought to have their own residence able to come in by the time they need the marriage ceremony. And after they become oldsters, they begin wanting to their children's future. "As the most financial gain suppliers, men area unit beholden to produce a home for his or her kids and purchase homes for them to produce security against something which may happen [12].

The flip facet of that's divorce: if a few split up, one among them wants a replacement residence, particularly if there area unit kids concerned. The typical age for divorce, in step with CAPMAS, is around thirty-five years previous, with 199,867 divorces recorded in 2015-a 14 July spike over 2014 divorces.

Around the world, owning a home is a lot of expenses in terms of maintenance, financing, insurance, and utilities compared to the choice of dealings. However, Egyptians still opt to inject their savings into home possession instead of leasing [13].

Adding to the content dimension is the monetary one. The property offers not simply an area to measure however conjointly a stable investment. In step with a March 2016 report by property securities firm Colliers International, The volatility of the Egyptian pound, besides traditionally high inflation rates, has attracted residents to the property investment market so as to secure their cash. In different words, the property has become a sort of wealth storage for patrons wanting to hedge against economic pressures. that explains The hedging choices area unit foreign currency, that is presently quite impossible; or gold, which needs an explicit level of understanding; or standard monetary instruments, that area unit either within the securities market or bank choices and aren't terribly stable at the instant. Consequently, investment in real assets at now preserves the buyers' wealth. Though liquidating these properties is tough, their worth is preserved [15].

The argument of property as a hedge against uncertainty underestimates verity magnitude of demand within the Egyptian market. Real demand continues to play a dominant role in Egyptian property by virtue of its population demographics and migration patterns. Currency and expected inflationary pressures ought to be seen as demand catalysts instead of an on the spot supply of demand." moon-faced with a lot of economic uncertainty and economic process, customers have a bigger incentive to shop for currently instead of wait. As a result, demand for property continues to outstrip provide, even amid pressures on developers to boost costs any because of exchange shortages, increasing construction prices and a weakening Egyptian pound [15]. The argument of real estate as a hedge against uncertainty underestimates the true magnitude of demand in the Egyptian market. Real demand continues to play a dominant role in Egyptian real estate by virtue of its population demographics and migration patterns. Currency and expected inflationary pressures should be seen as demand catalysts rather than an immediate source of demand." Faced with more economic uncertainty and rising prices, consumers have a greater incentive to buy now rather than wait. As a result, demand for real estate continues to outstrip supply, even amid pressures on developers to raise prices further due to foreign exchange shortages, increasing construction costs and a weakening Egyptian pound [15].

\subsection{The Looming Specter of Inflation}

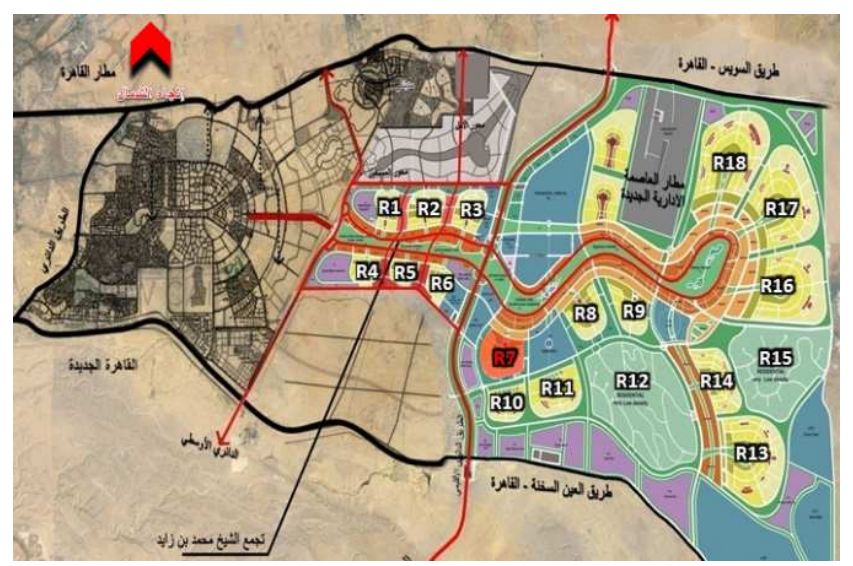

Figure 7. New Administrative Capital, Egypt.

Source:

https:/www.google.com/search?newwindow=1\&rlz=1C1GCEU_enEG827E G827\&biw $=1536 \&$ bih $=760 \&$ tbm $=$ isch\&sa $=1 \&$ ei=AJheXZfvGO-

Ongoing economic challenges are the biggest threat to the real estate sector's growth. Since late 2014, the country has suffered from a foreign currency shortage, severely hampering operations for dollar-dependent businesses. On November 3, 2016, the Central Bank of Egypt floated the Egyptian pound to eliminate a widening gap between official and parallel market rates. Before the float, the official bank rate had reached EGP 13 to the dollar, a $71 \%$ loss in value since January 2015; at the time of publication, the market placed the pound's value close to EGP 18 to the dollar.

The liquidity crisis spawned softening business sentiments, tighter import restrictions, and swelling inflation, with headline inflation reaching $19.4 \%$ in November 2016 . Under the economic reforms linked with the International Monetary Fund's recently approved USD 12 billion loan package, more subsidy cuts are inevitable, which will push inflation up even further. Prices are also going up under the Value Added Tax (VAT), which took effect in early September 2016 and replaced a $10 \%$ General Sales Tax. Passed to increase government revenues and shrink the budget deficit, the VAT imposes a $13 \%$ tariff on the majority of goods and services, with the rate increasing to $14 \%$ in FY 2017/18. Expected inflation to rise to $20 \%$ by the end of the year [5]. 


\section{FINANCIAL MARKETS}

Financial Markets refers to a marketplace where buyers and sellers participate in the trade. It is a platform that facilitates traders to buy and sell financial instruments/securities.

\begin{tabular}{|c|c|c|}
\hline & IMPORTANCE & FUNCTIONS \\
\hline $\begin{array}{l}* \mathrm{He} \\
* \mathrm{He} \\
* \mathrm{He} \\
\mathrm{bu}\end{array}$ & $\begin{array}{l}\text { in economic growth of country. } \\
\text { savers to become investors } \\
\text { businesses to raise money to expand their } \\
\text { ss. }\end{array}$ & $\begin{array}{l}\text { * Price Determination } \\
\text { * Mobilization of Funds } \\
\text { * Ensures Liquidity } \\
\text { - Saves Time and Money }\end{array}$ \\
\hline \multirow{5}{*}{$\begin{array}{l}\boldsymbol{\omega} \\
\mathrm{L} \\
\mathbf{0}\end{array}$} & \multicolumn{2}{|c|}{ Nature of Asset $\gg$ Stock, Bond, Commodity and Derivative Market } \\
\hline & \multicolumn{2}{|c|}{ Nature of Claim $\gg$ Equity market and Debt Market } \\
\hline & \multicolumn{2}{|c|}{ Maturity of Claim $\gg$ Money Market and Capital market } \\
\hline & \multicolumn{2}{|c|}{ Delivery Timing $\gg$ Cash market and Futures Market } \\
\hline & \multicolumn{2}{|c|}{ Organizational Structure $\gg$ Exchange Traded Market and Over The Counter } \\
\hline
\end{tabular}

Source: https://www.google.com/search?newwindow=1\&tbm=isch\&sa=1\&ei

Figure 8. Financial market Function, Important and types.

So far, demand for real estate has been bolstered by the strong prospect of appreciating property values, but soaring inflation will seriously affect housing affordability among consumers. Buyers also have to consider the cost of making the villa or apartment habitable, which includes labor and (mostly imported) raw materials for personalized renovations, plus all the furnishings. Given the social and cultural pressures toward homeownership, inflation may affect when and what type of property is bought-thus limiting how high developers can raise prices - but it is unlikely to stifle demand [16].

Property's appeal as an economic hedge could be affected by the banking sector's efforts to contain inflation. Immediately after floating the pound, the Central Bank raised key interest rates by 300 basis points, and some banks started offering Certificates of Deposit with $20 \%$ interest. Theoretically, as financial products become more attractive in the market, consumers could shift their wealth to these investment tools as alternatives to real estate [16].

Still, experts anticipate an increase in residential purchases for both primary and second homes throughout the next few years, as Egyptians continue investing in land and property to buffer against the economy's risks. The sustainable demand for real estate mitigates the constraints on the sector, which is a sigh of relief for real estate developers.

\subsection{Upping Supply with Urban Expansion}

In Feb 2016, the Egyptian government outlined its national goals for the coming 15 years in its Sustainable Development Strategy - Egypt's Vision 2030, which gives first priority to a comprehensive urban development plan involving large-scale expansion and the establishment of new cities, settlements, and communities across Egypt. The plan foresees the development of 80,000 feddans (336 sq. kilometers) a year to accommodate the galloping rise in the country's population. The strategy additionally options many national megaprojects and reforms to the $\$ 64000$ estate sector's restrictive framework. Following the Egypt Economic Development Conference in March 2015, the government secure to deliver 656,000 residential units for low- and middle-income voters as a part of its EGP one hundred twenty billion social housing program, thanks to being completed in April 2017. This program falls below the New body Capital megaproject, meant to ease the pressure on a densely packed Cairo by moving government services, embassies and plenty of businesses to an enormous new town over 700 sq. kilometers between New Cairo and own Sokhna. Construction has already started on infrastructure, road works and therefore the 1st residential community with up to twenty-five, units. In early October, the ministries of housing and investment signed a note of understanding with the Chinese state-owned company China Fortune exploitation to create a fourteen,000 feddan (58.8 sq. kilometers) sensible town within the new body capital. The USD twenty billion sensible cities square measure to be delivered over 3 phases [7].

last, Housing Ministry in early Nov that the auction of two,500 feddans (10.5 sq. kilometers) within the new body capital would be auctioned to the personal sector before the tip of the year, with land costs to be set by a ministry-formed committee. Investors are going to be ready to purchase entire plots or partner with the government on development [8].

Progress has been created on the Tahya Misr public 
housing, with President Abdel Fattah El Sisi formally inaugurating eleven,000 units in Mokattam in mid-2016, marking the completion of the primary 2 phases of the project. The EGP 1.5 billion comes were launched in early 2015, and therefore the Tahya Misr Fund coated virtually five-hundredths of the project's section. The EGP five hundred million third section was launched in January of this year with completion expected by early 2017 [17].

\subsection{Mortgage Math: Room for Growth}

The imbalance between supply and demand in Egypt's property market can be in some measure attributed to an unripe financial market. The market is dominated by off-plan sales, which is an equitable and flexible model for sellers and buyers. Because of the liquidity needed, however, this model is most practical for high-income buyers. Off-plan sales are fully paid in cash over seven to 10 years, with at least $10 \%$ down payment-making it cost-prohibitive for those in lower-income brackets.

It was noted that at the lowest end of the price range in Cairo suburbs, the price of a 130-square-meter flat may be around of LE 700,000. Assuming the amount will be paid over six years in monthly installments with a $10 \%$ down payment, this requires an upfront capital amount of EGP 70,000 and EGP 8,700 in monthly installments, calling for the household's monthly income to at least be EGP 25,000 [15].

Mortgages are a traditional financing option for buyers who have less cash on hand, allowing for a payment schedule that extends to up to 30 years. However, demand for mortgages in Egypt is still very low due to an immature mortgage market.

One problem is that by law, banks can only issue mortgages for legally registered properties. However, large portions of Egypt's inhabited property is not registered, either as a result of arduous registration procedures, formal ownership disputes, or because the residents are in informal settlements. Also, for consumers who can afford to cover payments in cash, long-term mortgage financing is needless. Loans are only granted following the completion of at least $30 \%$ of the unit's construction. Consumers are obliged to pay off-plan until the unit qualifies for a loan, at which point they would have paid for more than $70 \%$ of the unit's total value. This leaves only $30 \%$ of the price to be financed via mortgages, crowding out the majority of consumers who cannot afford a cash installment plan. Thus, mortgages have failed to gain much momentum over the past decade [14].

To improve access to financing for more Egyptians, the Central Bank in February 2016 increased the pool of authorized lenders to include mortgage finance companies for the first time and issued regulations to allow for longterm financing at low-interest rates. Egyptians earning up to EGP 1,400 per month are entitled to pay low mortgage interest rates (5\%). Individuals earning up to EGP 15,000 per month or families earning EGP 20,000 per month, considered as "above-average" earners, are eligible for mortgages with $10.5 \%$ annual interest for units costing up to EGP 950,000.
Additionally, banks can now use group insurance policies to cover the risks of lending to workers in the informal sector. Following these changes, mortgage values grew substantially. According to a report by the Egyptian Financial Supervisory Authority, mortgage values grew 30\% year on year in the first quarter of 2016. Thus, enhancing mortgage financing boosts the real estate industry's growth prospects, raises living standards and develops the financial market [13].

\subsection{Egypt's Housing Market Sees Continued Growth}

Favorable market conditions and high demand are driving investment in Egypt's residential real estate sector.

The Egypt Property Show (EPS) held in Dubai in April 2018 realized a total of $\$ 110 \mathrm{~m}$ in property sales, double the 2017 sales amount.

The event provided an opportunity for Egyptian property developers and real estate firms to access potential foreign investors and was attended by GCC nationals and Egyptian expatriates residing in the UAE.

The EPS will be held in the UK, US and Kuwait before the end of the year, and officials are predicting full-year sales equal to $\$ 250 \mathrm{~m}$.

The number of property listings on real estate company Property Finder Egypt's portal also rose sharply in the first quarter of 2018 , from 46,528 to 108,571 (a rise of $133 \%$ year-on-year) [15].

\subsection{New Provide Reflective of Positive Capitalist Surroundings, Sturdy Sector Performance}

The high level of investor interest is partly the result of government efforts to attract more foreign investment in real estate.

A new investment law, adopted last June, guarantees fair and equitable treatment for investors (foreign and local). Among other measures, the law gives investors the right to repatriate profits or receive international finance without restrictions, and entitles them to receive residence permits for the duration of investment projects.

Investor interest also reflects the resilience of residential real estate to the difficult conditions the broader economy has faced in recent years. In spite of the increase in construction costs and depressed disposal incomes in 2017 due to the flotation of the Egyptian pound toward the end of 2016 and the subsequent currency devaluation, there was a considerable rise in the demand for property in Cairo, real estate being perceived as a stable investment opportunity [17].

An annual report by real estate firm JLL indicates a 59\% increase in apartment sales and a $16 \%$ increase in villa sales in 2017. Spending in the rental sector, however, has been negatively affected by creeping inflation and the devaluation of the pound, recording $24 \%$ drop for apartments and $3 \%$ for villas.

This positive performance is expected to continue in 2018 . Higher GDP growth combined with lower inflation rates will encourage consumers, improve rental spending and prompt 
developers to implement new projects. The entrance of new real estate developers on the market increases competition and makes the provision of products that match the demand, and at the right price, essential. While opportunities abound, effective cost management will be a challenge, given that the price of land can be as much as $40 \%$ of the end price of a unit.

According to the IMF, GDP growth is forecast to rise from $4.3 \%$ last year to $5.2 \%$ this year and $5.5 \%$ in 2019 , while inflation dropped to its lowest rate (around 13\%) in two years this past April [12].

Housing demand in Cairo, one of the world's mega-cities, will continue to be driven by demographics. The Central Agency for Public Mobilization and Statistics figures show that Egypt's average annual population growth rate is $2.4 \%$ and that over $20 \mathrm{~m}$ of its population of around $97 \mathrm{~m}$ inhabitants live in Cairo. [13]

Ten thousand units were added to residential stocks in 2017. Completion and delivery of previously announced projects in gated residential communities could add an additional 70,000 units over the next three years. Nevertheless, according to real estate firm JLL, this figure is well below the estimated annual demand for 500,000 new homes [12].

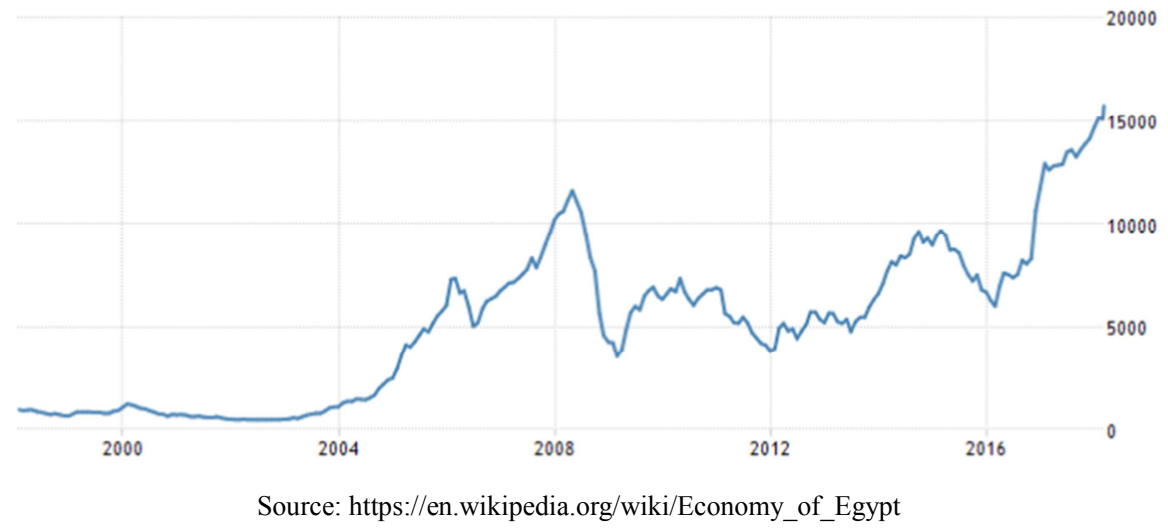

Figure 10. Egypt's Stock market growth (2017).

\subsection{Building New Cities to Alleviate Congestion}

A good portion of the new supply entering the market over the coming few years is located in and around the New Administrative Capital being built about forty-five kilometers east of Cairo, a $\$ 45 \mathrm{bn}$ project that the government is implementing to ease growing congestion in and around Greater Cairo, where the number of inhabitants is expected to reach $40 \mathrm{~m}$ by 2050 .

Inaugurated in October of last year, the new city is designed to house the Parliament and other major public entities. Covering an area of $700 \mathrm{sq}$. $\mathrm{km}$, it will have the capacity to house $5 \mathrm{~m}$ inhabitants by 2050 . The first stage of the project is will be completed by 2019 .

Other new cities are being developed to accommodate the rise in population. One example is New Mansoura City, which is constructed on 1680 hectares at a cost of $\$ 3.4 \mathrm{bn}$. It is expected to house an estimated future population of $1.5 \mathrm{~m}$ and will contain residential, tourist and industrial projects [14].

\subsection{Effect of the National Currency Devaluation on the Egypt's Real Estate Market}

The devaluation of the Egyptian pound in November 2016 led to a major slowdown in the real estate market. Since real estate development accounts for 10\% of Egypt's annual GDP growth, the slowdown could mean that Egypt's already struggling economy is in trouble.

There has been a significant increase in the price of building materials, such as bricks, and the increase in cost could result in an affordability problem on the supply line. Another problem is that Egypt's middle class lower classes could not afford the prices of many of the new apartments and residential compound units, which resulted in empty apartments and huge unfinished building projects [10].

\subsection{The Real Estate Market of the Past Decade}

Real estate market analyses show that the market was prospering significantly over the past year. Prior to the revolution, real estate value annual growth rate topped off at 15\%. However, The Egyptian stock market experienced a downturn due to the financial crisis and the revolution, and the stock market was struggling until the exchange rate policy was changed in November 2016 [11].

The real estate market was also impacted. Investors withheld from trading for a short period of time and investments in real estate dropped by 7\% between 2013 and 2014. Notwithstanding this decrease, the real estate market began to expand rapidly. Given the negative interest rate and the political upheaval, many investors decided that investing in real estate was their safest option, which resulted in tremendous growth. The first quarter of 2015 saw a $30 \%$ increase in real estate investments in Egypt. Dring the same period, residential unit prices rose by $20 \%$ and land prices by $35 \%$. This is just one an example of the continuing strength of the market since its positive performance in 2014 [11]. 


\section{Conclusion}

The Financial Market plays an extremely vital role in promoting the economy. It mobilizes savings, directing them to productive investment and facilitates capital inflows, thereby stimulating investment in physical and human capital. Furthermore, the Financial Market collects and analyzes information on investment opportunities, thus helping to channel savings to additional productive uses. By creating well-functioning transaction mechanisms for longterm financial instruments, the Financial Market generates a wide variety of wealth-creating opportunities for governments, companies, individuals, and financial institutions.

\subsection{Price Increases and High Demand}

The real estate boom led to huge price increases. For example, the price of a square meter in the 6th of October and New Cairo development doubled in two years (from $\$ 750$ to $\$ 1500)$. Between 2014 and 2016, the estimated demand for houses dropped from $45 \%$ to $33 \%$ (Oxford Business Group, 2016). The overall demand for properties (sale or rent) grew by $180 \%$ in the first quarter of 2017 , compared to the same quarter in 2016, the supply of real estate property increased by $55 \%$ in comparison to 2016 .

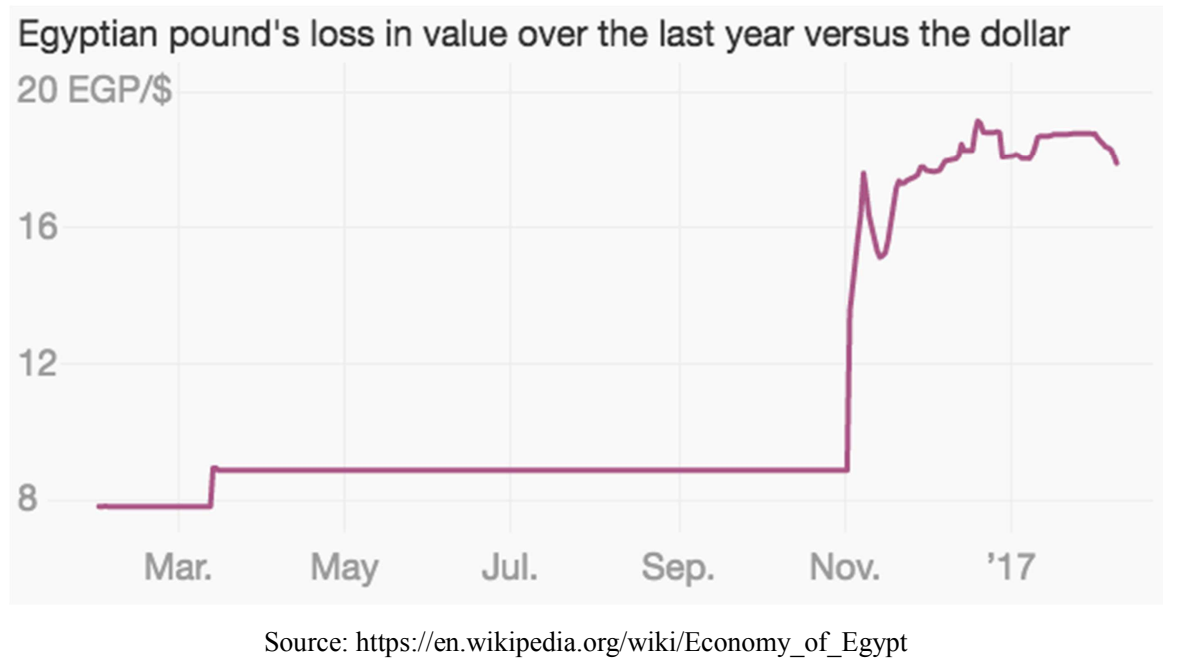

Figure 11. Egypt's Stock market growth (2017).

\subsection{The Devaluation of the Pound}

It took less than a month for the Egyptian pound to lose half of its value compared to the U.S. Dollar. At the start of November 2017, one U.S. Dollar could be exchanged for eight Egyptian pounds. At the end of the same month, the exchange rate was 1:18 As part of its economic reform strategy, the Egyptian government made the decision to float the Egyptian pound and cancel all currency exchange controls, with good reason. Currency exchange control had led to the creation of a large black market where dollars were priced at almost twice the official exchange rate. The uncertainty concerning the true value of the Egyptian pound made investment in, or importing from Egypt extremely unattractive. The reasoning behind the decision to float the exchange rate is that it will attract foreign investment and help to expand the Egyptian economy. Chris Jarvis, IMF Mission Chief for Egypt, predicts that the flexible exchange rate policy will boost Egypt's competitiveness abroad, promote tourism and attract foreign investment. According to the Central Bank of Egypt, floating the local currency will "allow market demand and supply dynamics to work effectively".

Following the devaluation of the Egyptian pound, the real estate market went into a new backslide. Real estate developers weren't sure what prices they should determine. A low price increase resulted in fast sales and many developers were sold out. Soon after, most property owners started to double their prices in an attempt to catch up with the currency devaluation. Buyers could not afford these price increases and transactions decreased substantially, creating an illiquid market.

In conclusion, the real estate market is clearly playing a major role in Egypt's economic growth due to all the reasons explained above. Therefore, the government and the private sector must focus on this sector by developing different strategies designed to control market growth by applying reasonable prices and policies.

\section{Research Objective}

The main objective of the research is to approve that the real estate sector is a key player in the economics growth of Egypt in the light of hall urban development by explaining and state its impacts on the urban development.

\section{Research Hypothesis}

The research is assume that there is a strong relation between the real estate behavior and the economics growth of Egypt. 


\section{References}

[1] Aghion, P., G-M. Angeletos, A. Banerjee, K. Manova, 2005, "Volatility and Growth: Financial Development and Cyclical Composition of Investment." Mimeo.

[2] Aghion, P., P. Bacchetta, and A. Banerjee. 2004. "Financial Development and the Instability of Open Economies." NBER Working Paper No. 10246, Cambridge, MA

[3] Alba, P., S. Al-Shawarby, and F. Iqbal. 2004. "Fiscal and Public Debt Sustainability in Egypt." Middle and North Africa Working Paper No. 38. The World Bank, Washington DC.

[4] Economic growth in Egypt constructions and determinants, 2016, Anton Dobronogov and Farrukh Iqbal Working Paper 0420.

[5] Hanaa Kheir-El-Din and Hala Abou-Ali, Inflation and growth in Egypt is there a threshold effect?, June 2008, Working Paper No. 135.

[6] Summary Notes on the RTD entitled: "Will Egypt Face a Real Estate Bubble?" Held on September 18, 2018, http://www.eces.org.eg/MediaFiles/events/3d067c7d.pdf.

[7] Selected Investment Opportunities in Egypt, Brief- April 2016, and Ministry of investment.

[8] Stats on Supply Vs Demand in Real Estate, 2018 Report, https://www.propertyfinder.eg/blog/en/2018-report-stats-onsupply-vs-demand-in-real-estate/

[9] Egypt's house prices falling sharply; but outlook remains positive, LALAINE C. DELMENDO June 20, 2019, https://www.globalpropertyguide.com/MiddleEast/Egypt/Price-History

[10] African Finance for the $21^{\text {st }}$ century, high level seminar organized by IMF Institute, in collaboration with joint African institute, Tunisia, 2005. https://www.imf.org/external/np/seminars/eng/2008/afrfin/pdf/ senbet.pdf
[11] 11Real estate the power of property, 2016, American chamber of commerce in Egypt. https://www.amcham.org.eg/publications/industryinsight/issue/1/Real-Estate $\%$ E2\%80\%99s-Big-Picture.

[12] Oxford business group, The report of Egypt 2018, https://oxfordbusinessgroup.com/egypt-2018

[13] Oxford business group, Egypt's housing market sees continued growth, 2018 https://oxfordbusinessgroup.com/news/egypt $\%$ E2\%80\%99shousing-market-sees-continued-growth

[14] Egypt's Real Estate Market: Looking at the Bigger Picture, Egypt today, 2018 https://www.egypttoday.com/Article/3/58148/Egypt $\%$ E2\%80 $\% 99$ s-Real-Estate-Market-Looking-at-the-Bigger-Picture

[15] Impact of the Egyptian Pound Devaluation on the Real Estate Market in Egypt, house solutions, 2018. https://www.housesolutionegypt.com/blog/Impact-Of-TheEgyptian-Pound-Devaluation-On-The-Real-Estate-Market-InEgypt

[16] SAHAR NASR, Access to Finance and Economic Growth in Egypt, the World Bank, 2018. S.N 41305 http://siteresources.worldbank.org/INTEGYPT/Resources/Acc ess_to_Finance.pdf

[17] Real Estate Industry - Annual Report, 2018. Report linker. https://www.reportlinker.com/ Estate/6274/Realmarket-report/RealEstate?utm_source $=$ adwords $1 \& u t m \_$medium $=$cpc\&utm_camp aign $=$ Financial_Services\&utm_adgroup $=$ Real_Estate_Market Reports\&gclid $\overline{\mathrm{d}}=\mathrm{CjwKCAjw}^{-}{ }^{-} \mathrm{PqBRBIEiwA} \overline{7} 1 \mathrm{rmta} \overline{\mathrm{g}} \mathrm{vbqBh}$ ybYo-rojJqneJRKpt_s4hGt5BZfDeduP3IqlqWsUGt3xoCgBsQAvD_BwE. 